\title{
The Effect Of Organizzation Culture, Rewards, Job Satisfaction And Job Stress On Lecturer's Performance At UIN Ar-Raniry anda Aceh
}

\author{
${ }^{1}$ Iis Marsithah, ${ }^{2}$ Benyamin, ${ }^{3}$ Nasrun \\ ${ }^{1}$ Doctoral Student State University of Medan \\ ${ }^{2}$ Profesor, Promotor State University of Medan \\ ${ }^{3}$ Profesor, Co-Promotor State University of Medan \\ *Corresponding Author: \\ E-mail: iismarsithah@yahoo.com
}

\begin{abstract}
.
The purpose of this study was to find out and examine: (1) the lecturer's performance model built on associative causal relationships between exogenous variables and endogenous variables, (2) the effect of organizational culture to job satisfaction, (3) the effect of rewards to job satisfaction, (4) the effect of organizational culture to job stress, (5) the effect of rewards to job stress,(6) the effect of organizational culture to lecturer's performance, (7) the effect of rewards to lecturer's performance, (8) the effect of job satisfaction to lecturers performance, and, (9) the effect of job stress to lecturers performance. The population is all lecturer as many as 486 people. The research sample of 219 people was determined by the Slovin formula. Data collection is done by using a questionnaire with five answer choices. The sampling technique were used proportional random sampling. The instruments were used first tried out to respondent outside the sample to obtain validity and reliability instruments. Validity test uses Product Moment correlation, while to test its reliability with Alpha formula from Cronbach. Before testing the hypothesis, especially before the test is calculated, the requirements of the analysis include: normality data test and regression linearity test.The results showed (1) Obtained the lecturer's performance model UIN Ar-Raniry Banda Aceh, (2) there is positive direct effect of organizational culture to job satisfaction $1,9 \%$, (3) there is positive direct effect of rewards to job satisfaction 1,9\%, (4) there is negative direct effect of organizational culture to job stres $11,2 \%$, (5) there is negative direct effect of rewards to job stress $2 \%$, (6) there is positive direct effect of organizational culture to lecturer's performance 7,9\% include indirect effect through job satisfaction $0,6 \%$ and job stress $1,8 \%$, (7) there is positive direct effect of rewards to lecturer's performance 2,8\% include indirect effect through job satisfaction $0,4 \%$ and job stress $0,7 \%,(8)$ there is positive direct effect of job satisfaction to lecturer's performance 1,5\%, and (9) there is positive direct effect of job stress to lecturer's performance 3\%.Based on the acceptance of the research hypothesis, it is found a fixed model that describes the structure of causal relationships between organizational culture, rewards, job satisfaction, job stress and lecturer's performance at UIN Ar-Raniry Banda Aceh. The organizational behavior has bigger influence than the other variable to lecturer's performance. The next variable was job stress, rewards, and job satisfaction has lowest influence than the other variable to lecturer's performance.
\end{abstract}

Keywords: organizational culture, rewards, job satisfaction, job stress and lecturer's performance.

\section{INTRODUCTION}

Structuring human resources needs to be pursued gradually and continuously through a quality education system both in the formal, informal and non-formal education pathways, from basic education to tertiary education.. According to Yuhandi (2016: 43) Higher education as the last level of formal education has an important and strategic role in producing quality human resources and improving science and technology (IPTEK). Through higher education there is a process of providing added value in knowledge, attitudes and skills to students so as to create highly competent human resources. Furthermore, Government Regulation Number 60 of 1999 concerning higher education states that the goals of higher education are: (1) Preparing students to become members of society who have academic and / or professional abilities who can apply, develop and / or enrich their knowledge of science, technology and or the arts; and, (2) Develop and disseminate science, technology and / or arts and seek to use them to improve the standard of social life and enrich the national culture. 
According to Soehadi (2013: 67) that the quality of education quality can be characterized by whether or not the graduates of these educational institutions are relevant to the needs of society. The condition of the irrelevance of the quality of graduates of educational institutions can be indicated by the large number of unemployed graduates. According to Nawawi (2016: 63) performance is something that is achieved, demonstrated achievement and work ability. Performance is said to be high if a work target can be completed at the right time or does not exceed the time limit provided. Performance becomes low if it is completed beyond the allotted time limit or is not completed at all.

Based on data from the Central Statistics Agency (BPS), unemployment in Banda Aceh in 2020 reached 136 thousand people with a percentage of 6.20 percent. Where, according to the Head of BPS Banda Aceh Ihsanulrijal, the unemployment rate is the highest at 8.30 percent of undergraduate graduates and 8.15 percent of high school graduates. This causes Banda Aceh to be a province where the unemployment rate is still higher than other provinces in Indonesia.

Graph 1. Percentage of Unemployment Rate in Aceh Province 2015-2019

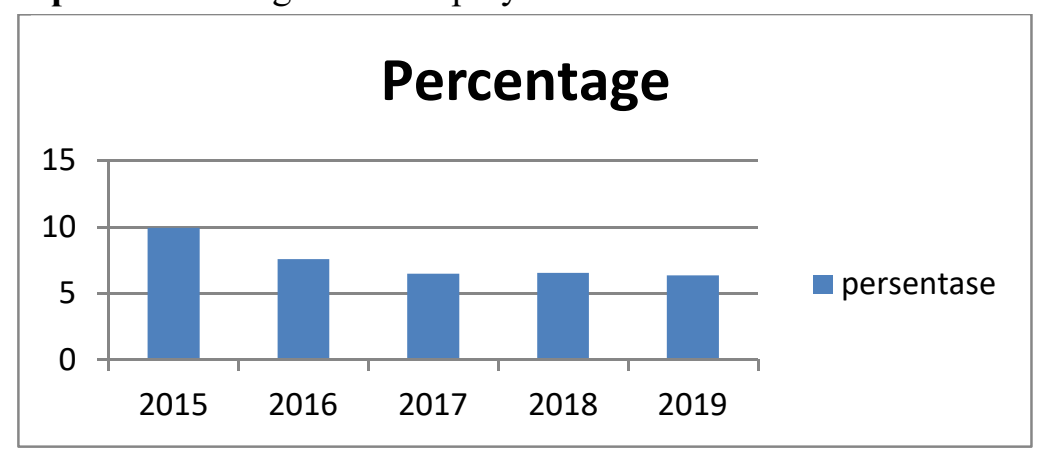

Source: Banda Aceh Central Statistics Agency Documentation 2015-2019

Based on Graph 1. Unemployment rate in Banda Aceh is increasing from year to year. In 2015 it reached 9.93 percent, in 2016 it decreased to 7.57 percent, in 2017 it became 6.49 percent, then in 2018 it increased by 6.55 percent and in 2019 the unemployment rate reached 6.36 percent. Lecturers who have good performance are lecturers who have the ability to carry out their duties and obligations towards their organization by working seriously, provide the best service to students, proactively improve themselves according to the vision, mission and goals of the campus, accept additional assignments besides learning assignments in the classroom, provide the best service to students, remain loyal to be a lecturer, always maintain the good name of the campus, avoid self-deprecation, and are proud to be a lecturer.

In reality this is far from expectations. Based on a preliminary study conducted in January 2020 on 144 lecturers at 4 (four) faculties at UIN Ar-Raniry Banda Aceh, namely: Tarbiyah and Teaching Faculty 45 lecturers, Faculty of Da'wah and Communication 35 lecturers, Faculty of Syari'ah and Law 35 lecturers, and Faculty of Adab and Humanities 29 lecturers. Found data on lecturer performance which can be seen in the following table:

Table 1. Lecturer Performance at UIN Ar-Raniry Banda Aceh

\begin{tabular}{|c|l|c|c|}
\hline No & \multicolumn{1}{|c|}{ Description } & $\begin{array}{c}\text { Number of } \\
\text { Lecturers }\end{array}$ & $\begin{array}{c}\text { Percentage } \\
\%\end{array}$ \\
\hline 1 & Lecturers do not work earnestly & 65 & 45 \\
\hline 2 & Lecturers do not provide the best service & 72 & 50 \\
\hline 3 & Lecturer work responsibility is low & 65 & 45 \\
\hline 4 & Lecturer discipline level is low & 65 & 45 \\
\hline 5 & Lecturers' desire to excel and develop low self & 58 & 40 \\
\hline
\end{tabular}

Table 1 above shows that: (1) the lecturers do not work seriously (45\%), This can be seen from the number of lecturers who do not have learning media or learning materials to teach in class; (2) Lecturers do not provide the best service to students $(50 \%)$, it is shown by the number of lecturers who teach not in accordance with the content of the Semester Program Plan (SPP), does not have a teaching manual, does not prepare power points or materials for teaching; (3) Low work responsibility (45\%), It is shown by the 
number of lecturers' assignments that have not been carried out as they should. (4) The level of discipline of lecturers is low (45\%), It is shown by the fact that there are still many lecturers who are late for class to teach, and close the lesson by leaving the class before class ends. (5) The desire for achievement and selfdevelopment is still low (40\%), This is indicated by the low desire of the lecturers to continue their education due to the age factor, busy with a side job to support his economic life, lack of time, or because the income from a side job is quite promising.

According to Armstrong and Baron (2011: 200) Performance is the result of work that has a strong relationship with the strategic objectives of the organization which are influenced by ability, motivation, perceptions and opportunities as Figure 1 below:

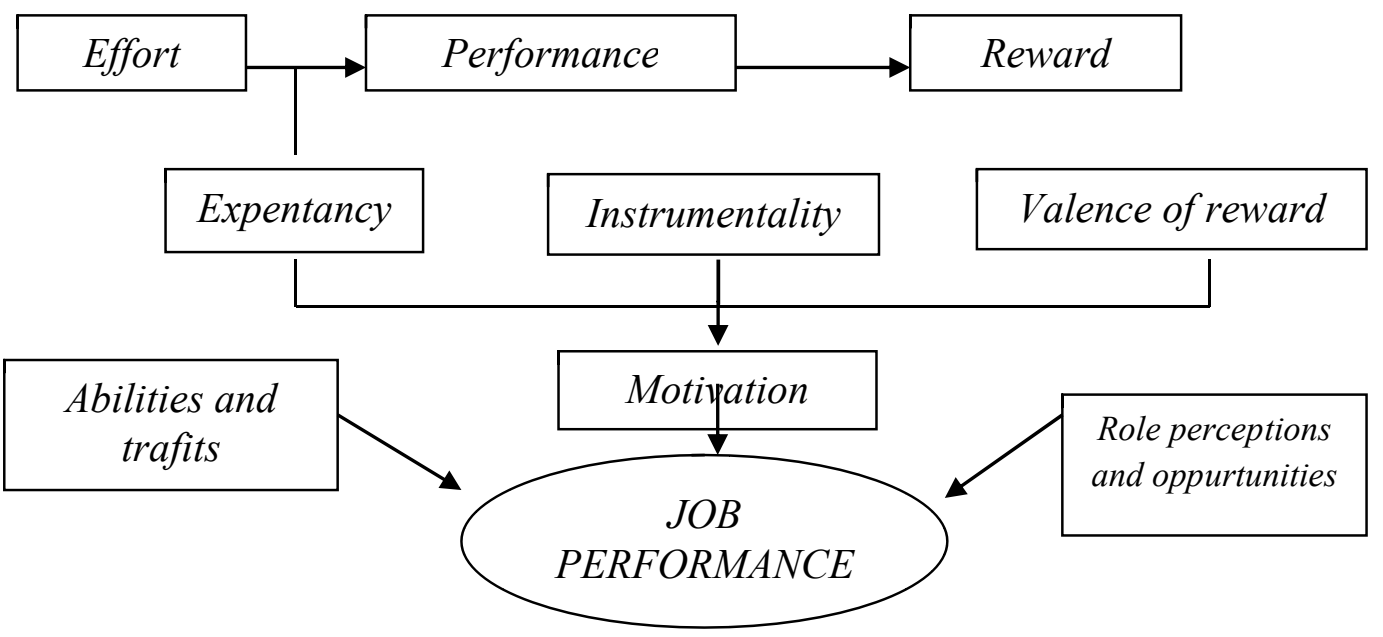

Fig 1. Overview of Expectancy Theory oleh Amstrong dan Baron (2011:200)

Kreitner dan Kinicki (2012:212) defines that organizational culture is an organizational glue that binds organizational members through adhered values, symbolic tools, and social goals to be achieved. Work culture has a very strategic role to encourage and improve the effectiveness of organizational performance, both in the short and long term. Work culture acts as a social glue that binds fellow members of the organization together in a common vision and goal.

In addition, teacher performance is inseparable from the influence of the reward system, according to Sihotang (2017:220) reward is the overall arrangement of remuneration for employees and managers, both in the form of financial and goods and services received by each employee; Furthermore, Fraser (1992:56) suggests the importance of a reward system as an indicator of job satisfaction that is difficult to estimate, this is due to employees' views on money or direct rewards is subjective and is something that is very typical in the industry, but basically there are allegations of injustice in providing wages and salaries is a source of employee dissatisfaction with the reward system which in turn can lead to disputes and low morale from the employees themselves..

Fulfillment of these expectations will provide satisfaction, but if not fulfilled it will give a sense of dissatisfaction. Job satisfaction in general is a picture of the fulfillment of one's hopes for an object. High job satisfaction is needed in organizations so that workers can do their job happily, which leads to good performance. Greenberg and Baron (2014:179) suggesting guidelines to help increase job satisfaction, namely: (1) have the opportunity for promotion; (2) the job itself or make work fun; (3) have a salary; (4) have good co-workers so that they can design work that is more attractive and fun; and (5) have good and pleasant supervision from the leadership.

In the workplace, stress is often unavoidable according to the type of work. Conflict that is not resolved properly and quickly results in anxiety, and excessive anxiety will cause stress. According to Luthans (2012:440) stress is an adaptive response to external situations that produce physical deviations, psychological, and / or behavior of members of the organization. Furthermore, he emphasized that usually stress is caused by something bad and fun. Stress caused by something bad is called negative stress, while stress caused by something fun is called positive stress. Gibson, et al (2014: 16) also explain that stress is an 
adaptive response mediated by individual characters and psychological processes resulting from actions, situations, and environmental events that produce excessive psychological and physical needs in a person.

Newstrom (2007:353) introduced stress as a general term for the pressure people feel in life. When stress occurs, it can cause problems in one's emotions, thought processes, and physical condition. When stress is higher, people will show various symptoms that worsen their performance and health, which will threaten their ability to face their environment.

\section{METHOD}

The method used in this research is a quantitative method with a survey approach using path analysis. This research was conducted for 3 (three) months starting from November 2020 to January 2021. This research is that all lecturers have permanent status as Civil Servants which is in the vicinity of the Ar-Raniry State Islamic University (UIN) Banda Aceh, with a total of 486 people and spread across all work units at the Ar-Raniry State Islamic University Banda Aceh, thus the data sample obtained was 219. Sampling in this study was carried out by means of stratified proportional random sampling to find out the specifics How is the state of the lecturer's performance of each stratum based on the provisions of the sample from the population developed by Arikunto (2013:120) and Riduan (2012:49) using the formula from Slovin at an error level of $5 \%$.

\section{RESULT AND DISCUSSION}

After describing the research data, then the frequency distribution of each research variable is presented in the following figure.

(1) The frequency distribution of the Organizational Culture Variable (X1) score can be shown in Figure 2 as follows.

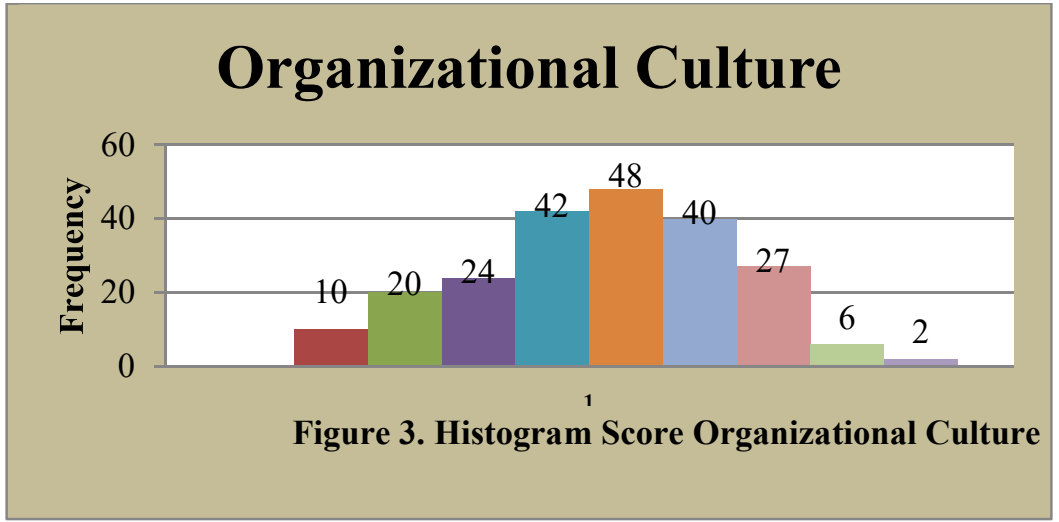

Based on the variable tendency level $\left(\mathrm{X}_{1}\right)$, it can be seen that 58.45 percent of the research subjects, namely the Lecturer at UIN Ar-Raniry Banda Aceh stated that the organizational culture was in the sufficient category.

(2) The frequency distribution of employee benefit variable scores $\left(\mathrm{X}_{2}\right)$ can be seen in Figure 4 below.

\section{Employee Benefit}

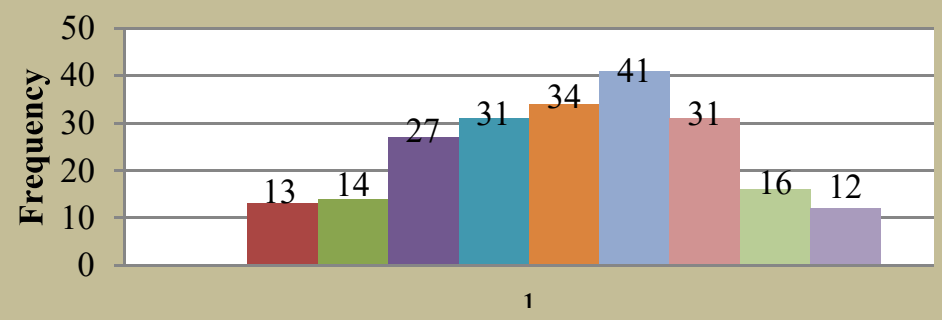

Figure 4. Histogram Score Employee Benefit 
Based on the variable tendency level $\left(\mathrm{X}_{2}\right)$ it can be seen that 67.12 percent of the research subjects, namely the Lecturers of UIN Ar-Raniry Banda Aceh have employee benefits that are in the sufficient category.

(3) The frequency distribution of the job satisfaction variable score $\left(\mathrm{X}_{3}\right)$ can be seen in Figure 5 below.

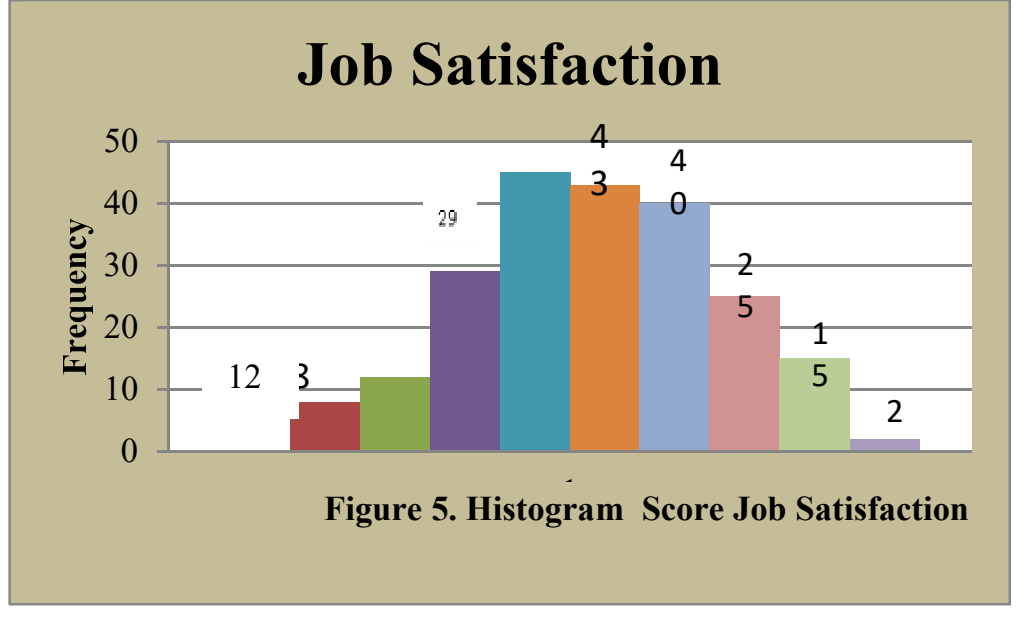

Based on the variable tendency level $\left(\mathrm{X}_{3}\right)$ it can be seen that 69.41 percent of the research subjects, namely the Lecturers of UIN Ar-Raniry Banda Aceh, have job satisfaction which is in the sufficient category.

(4) The frequency distribution of the work stress variable score $\left(\mathrm{X}_{4}\right)$ can be seen in Figure 6 below.

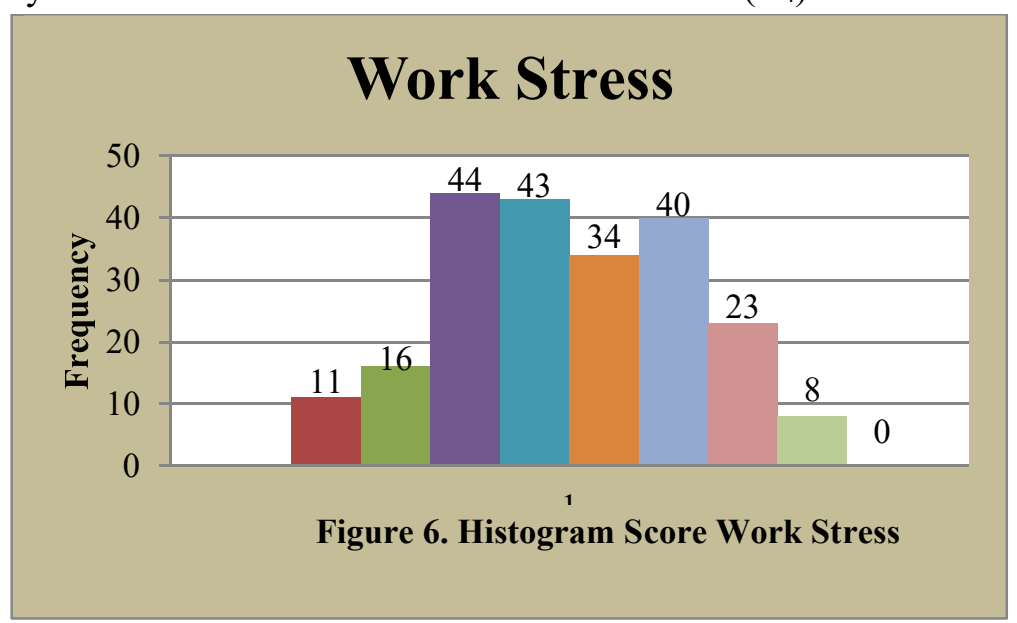

Based on the variable tendency level $\left(\mathrm{X}_{5}\right)$, it can be seen that 67.58 percent of the research subjects, namely the Lecturers of UIN Ar-Raniry Banda Aceh, have work stress which is in the sufficient category.

(5) The frequency distribution of lecturer performance variable scores $\left(\mathrm{X}_{5}\right)$ can be seen in Figure 7 below.

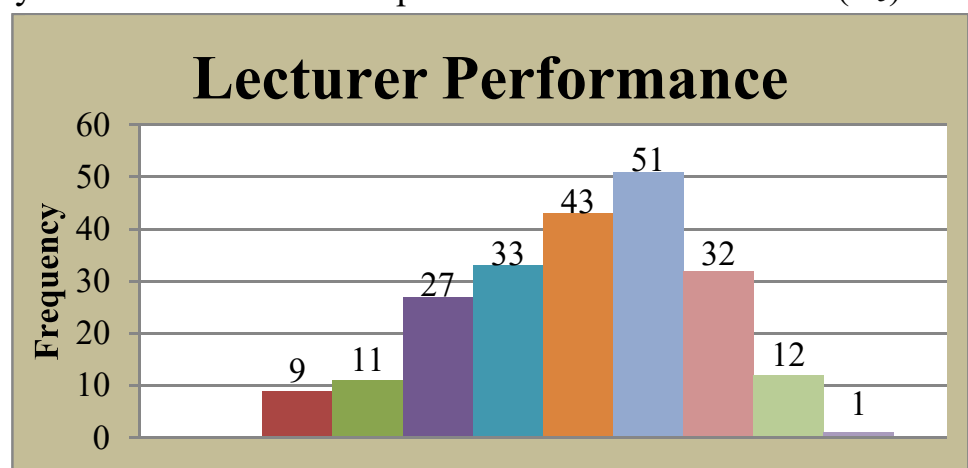

Figure 7. Histogram Score Lecturer Performance

Based on the variable tendency level (X5), it can be seen that 56.16 percent of the research subjects, namely the Lecturers of UIN Ar-Raniry Banda Aceh, have the performance of lecturers in the moderate category.

Based on the causal model that is theoretically formed a path diagram is obtained as in the following figure: 


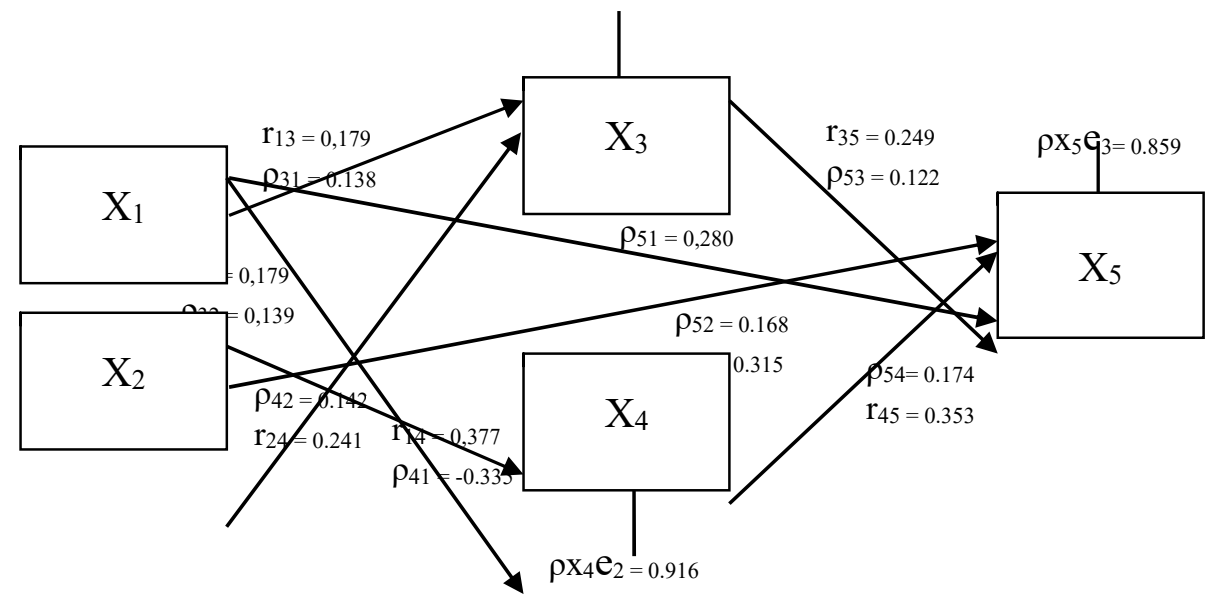

Fie 8. Research Variable Path Diagram

Information: $\quad \mathrm{X}_{1}=$ Organizational Culture

$\mathrm{X}_{2}=$ Employee Benefits

$\mathrm{X}_{3}=$ Job Satisfaction

$\mathrm{X}_{4}=\mathrm{Job}$ Stress

$\mathrm{X}_{5}=$ Lecturer Performance

$\mathrm{e}_{1}, \mathrm{e}_{2}, \mathrm{e}_{3},=$ Residual Variables (error)

The research findings show that the organizational culture variable has a greater influence on the improvement of the lecturers' performance at UIN Ar-Raniry Banda Aceh when compared to other variables, So it can be said that if you want the performance of the lecturers to improve properly, it should first increase the organizational culture, then it will be followed by a decrease in work stress levels, improving employee benefits, and strengthening job satisfaction. The results of this study also explain that the job satisfaction of lecturers has a relatively small effect on the performance of the lecturers at UIN Ar-Raniry Banda Aceh when compared to other variables.

\section{CONCLUSION}

Based on the data that has been obtained from the field, a number of facts can be found and based on the analysis of the research data, the following conclusions can be drawn:

1. All indicators set based on theory are deemed valid to construct latent variables of organizational culture (7 indicators), employee benefits (4 indicators), job satisfaction (5 indicators), job stress (4 indicators) and lecturer performance (4 indicators). In other words, all 24 indicators are declared valid for constructing latent variables. This means that the indicators and theories used in the research are still relevant to describe the real conditions.

2. The main fixed model path (final fixed model) which is found empirically is the same as the path of the theoretical model built on the basis of this research theory.

3. Based on the Fixed Main Model, it was found that the overall path coefficient was significant, namely (1) $\rho_{31}$, which means that an increase in organizational culture will increase job satisfaction with the path coefficient reaching 0.138 and the correlation coefficient reaching 0.179 ; (2) $\rho_{32}$ which means that an increase in employee benefits will increase job satisfaction with the path coefficient reaching 0.139 and the correlation coefficient reaching 0.179 ; (3) $\rho_{41}$ which means that an increase in organizational culture will reduce the level of work stress with the path coefficient reaching -0.335 and the correlation coefficient reaching -0.377 .; (4) $\rho_{42}$ which means that an increase in employee benefits will reduce work stress with the path coefficient reaching -0.142 and the correlation coefficient reaching -0.241 ; (5) $\rho_{51}$ which means that an increase in organizational culture will improve the performance of lecturers with the path coefficient reaching 0.280 and the correlation coefficient reaching 0.418 ; (6) $\rho_{52}$ which means that the increase in employee benefits will increase the performance of lecturers with the path 
coefficient reaching 0.168 and the correlation coefficient reaching 0.315 ; (7) $\rho_{53}$ which means that an increase in job satisfaction will improve the performance of lecturers with the path coefficient reaching 0.122 and the correlation coefficient reaching 0.249 ; and (8) $\rho_{54}$ which means that an increase in work stress will reduce the performance of lecturers with the path coefficient reaching -0.174 and the correlation coefficient reaching -0.353 .

4. Fixed Main Model which is found is basically consistent with the proposed theoretical model, namely 8 (eight) hypotheses that are built theoretically.

5. 5. The direct influence of organizational culture variables, employee benefits, job satisfaction and overall lecturer work stress on lecturer performance reached $18.7 \%$., while the indirect effect of the four variables on the principal's performance reached $7.5 \%$. Direct influence, indirect influence of organizational culture variables, employee benefits, job satisfaction and job stress on the performance of lecturers at UIN Ar-Raniry Banda Aceh and non-pathways (Unanalyzed and Spurious) reached 26.2\% so that other influences outside the variables that have been determined in this study reached $73.8 \%$.

\section{REFERENCES}

[1] Al-Rasyid, Harun. (1997). Statistika Sosial. Bandung: Program Pascasarjana Unpad.

[2] Amstrong, Michael \& Baron, A. (2011). Performance Management: The New Realities, Institute of Personnel and Development, New York.

[3] Arikunto, Suharsimi. (2013). Prosedur Penelitian Suatu Pendekatan Praktik. Jakarta: Rineka Cipta

[4] Frasser, T, M. (1992). Stres dan Kepuasan Kerja: Acuan Mencari Alternatif untuk Meningkatkan Kepuasan Kerja Karyawan dalam Lingkungan Kerja yang Sesuai. Alih Bahasa L. Mulyana. Jakarta: PT. Pustaka Binaman.

[5] Gibson, J.L, Ivancevich, J, M, Donnelly, Jr, J, H. and Konopashe, R. (2014). Organizational Behavior, Structure, Processes. New York: Mc. Graw Hill Companies, Inc.

[6] Greenberg, J. and R. A. Baron (2014). Behaviar in Organizations: Understanding \& Managing The Human Side Of Work. New Jersey: Prentice-Hall. International.

[7] Kreitner, Robert and Kinichi,.Angelo. (2012). Organizational Behavior: New York: Irwin / McGraw-Hill Companies. Inc.

[8] Nawawi, Hadari. (2016). Evaluasi dan manajemen kinerja di lingkungan perusahaan dan industri. Yogyakarta: Gadjah Mada University Press

[9] Newstrom John W dan Davis Keith,.(2007). Perilakudalam Organisasi. Edisi ketujuh.Alih Bahasa :Agus Dharma. Jakarta: Erlangga.

10] Riduan. (2012). Metode \& Teknik Menyusun Proposal Penelitian. Bandung: Alfabeta.

[11] Sihotang, A. (2017). Manajemen Sumber Daya Manusia. Jakarta: Pradnya.

[12] Soehadi, A.W dan Ardianto, E (2013) Consumunity Marketing: Strategi Pemasaran Berbasis Comunitas. Jakarta: Prasetya Mulya Publishing.

[13] Yuhandi (2016). Times Higher Education Suplement (THES), Jakarta: Gramedia Pustaka Utama. 